\title{
A COSMOPOLÍTICA DOS ORIXÁS: ENCRUZILHADAS ENTRE HUMANOS, DIVINDADES E NATUREZA ${ }^{1}$
}

\author{
Jean Filipe Favaro \\ Hieda Maria Pagliosa Corona ${ }^{2}$
}

Resumo: Na religiosidade afro-brasileira apresentada, as encruzilhadas, além de se tratarem de lugares sagrados regidos pelas açóes e significados de Exu, onde eclodem interaçôes sócio-cósmicas de diversas ordens, também retratam uma lógica de multiplicidade, que se penetram repletos de sentidos nas relaçóes humanas, destacando uma ampla rede de política cósmica. Por meio de uma etnografia num terreiro de Umbanda, Quimbanda e Candomblé, alicerçados nas ferramentas teórico-metodológicas da Teoria Ator-Rede, analisamos as encruzilhadas conformadas pela rede de actantes nas inter-relaçóes entre humanos, divindades e natureza, entendendo-as como operaçóes cosmopolíticas, mapeando os actantes e descrevendo os saberes mobilizados em açóes concretas. Os conhecimentos que circundam os conceitos e eventos mencionados e cartografados são complexos e ricos, permitem traduzir o cosmos em termos e sentidos que expressam fluxos e entrecruzamentos entre o mundo social, espiritual e da natureza, com diversidade de actantes, descentralizando os humanos do desenho cartográfico.

Palavras-chave: Encruzilhada; Exu; Cosmopolítica; Espiritismo.

1 Como citar: FAVARO, Jean Filipe; CORONA, Hieda Maria Pagliosa. A cosmopolítica dos Orixás: encruzilhadas entre humanos, divindades e natureza. Debates do NER, Porto Alegre, v. 1, n. 37, p. 95-124, 2020.

2 Jean Filipe Favaro é doutorando no Programa de Pós-Graduação em Desenvolvimento Regional da Universidade Tecnológica Federal do Paraná, Pato Branco, Brasil. E-mail: jeanfilipe.favaro93@gmail.com. Hieda Maria Pagliosa Corona é professora da mesma Universidade. E-mail: pagliosa@utfpr.edu.br.

Debates do NER, Porto Alegre, ano 20, N. 37, P. 95-I 24, JAN./Jul. 2020 


\begin{abstract}
In the Afro-Brazilian religiosity presented here, the crossroads portray a logic of multiplicity, full of meanings in human relations, highlighting a wide network of cosmic politics. They also represent sacred places ruled by the actions and meanings of Exu, where socio-cosmic interactions of different orders emerge, also. Through ethnography in a Umbanda, Quimbanda and Candomblé temple (terreiro), based on the theoretical-methodological tools of the Actor-Network Theory, we analyzed the crossroads defined by the network of actants in the interrelationships among humans, deities and nature, understanding them as cosmopolitical operations, mapping the actants, and describing the knowledge mobilized into concrete actions. The knowledge that surrounds the mentioned and mapped concepts and events are complex and rich, allowing to translate the cosmos in terms and meanings that express flows and intersections among the social, spiritual, and the natural world, with a diversity of actants, decentralizing humans from cartographic drawing.
\end{abstract}

Keywords: Crossroads; Exu; Cosmopolitics; Spiritism.

\title{
INTRODUÇÃO
}

As religiōes afro-brasileiras são constituídas por saberes, significados, magia, politeísmo, e práticas diversas que propiciam o cruzamento do mundo dos espíritos com a sociedade que se agrega nos terreiros ${ }^{3}$. De modo genérico, a constituição destas religiosidades se deu pelos cruzamentos e hibridismos de matrizes ontológicas diversas, com raízes nas múltiplas etnias africanas ${ }^{4}$,

3 Termo êmico para designar um templo religioso afro-brasileiro. Os termos casa, abaça, ilê-axé, terreira, também podem ser empregados como análogos ao termo terreiro. Vale ressaltar que o vocábulo êmico estará destacado com grafia itálica no percorrer do texto.

4 Conformada historicamente na integração da diversidade de povos bantos e sudaneses, que trouxeram consigo o culto aos Orixás, Voduns, Inkices e outras divindades e ancestrais (Bastide, 1971).

Debates do NER, Porto Alegre, Ano 20, N. 37, P. 95-I 24, JAn./Jul. 2020 
nas práticas de Pajelança indígena ${ }^{5}$, no Catolicismo popular ${ }^{6}$ e também Espiritismo kardecista ${ }^{7}$, que com rupturas, continuidades, transformaçóes, sincretismos, e resistências diversas através de séculos, retratam um arsenal epistêmico complexo, pelo qual não existe separação entre o mundo biofísico e supranatural (Bastide, 1971; Ferretti, 2013).

Nas mais diversas formas de religiosidades afro-brasileiras, em especial práticas subsidiadas pelas Umbandas, Quimbandas, Linhas Cruzadas, a encruzilhada emerge como categoria êmica que traduz a multiplicidade de práticas, formas e matrizes culturais. Anjos (2006) anuncia que as encruzilhadas perpassam o início de todo processo agenciamento dos coletivos afrorreligiosos, apresentando diversas situaçóes em que esta categoria se faz potente, como, por exemplo, nas diferenças entre a linha de Umbanda e a linha de Exu, nos vocábulos êmicos (cruzamentos, assentamentos, cruzar, caminhos, etc.), nas oferendas iniciais dos terreiros, nos territórios sagrados, nos corpos dos médiuns durante a incorporação das entidades, acepçóes morais de bem e mal, nas aberturas de caminhos, dentre muitos outros agenciamentos do povo de santo, conformados numa perspectiva "espaço-temporal do mundo" que fundamenta a cartografia sócio-cósmica dos actantes que se reúnem nos terreiros (Anjos, 2006, p. 19).

Apresentamos a noção de actantes, termo emprestado da semi-ótica por Latour $(2004,2012)$, que o emprega como uma denominação neutra para atores sociais, que são tanto humanos quanto não humanos (deuses, minerais, máquinas, animais, vegetais, e diversos seres e coisas que interagem com a

5 Religiōes como o Catimbó, Jurema, Terecô, Babaçuê, Candomblés de Caboclo, Umbandas e Quimbandas são repletas de elementos indígenas em suas liturgias e entidades cultuadas (Bastide, 1971).

6 O Catolicismo além de estar presente na forma do culto aos santos, também se faz presente em seus aspectos mágicos e populares, como por exemplo, no culto às almas descrito por Augras (2012).

7 As macumbas cariocas, que tinham influências de rituais angola-congoleses, também eram destacadas pelos cultos aos ancestrais, que possibilitaram fusóes com o espiritismo kardecista no final do século XIX e início do século XX (Bastide, 1971).

Debates do NER, Porto Alegre, ano 20, N. 37, P. 95-I 24, JAN./Jul. 2020 
sociedade), que nos permite aceitar "como atores completos, entidades que foram explicitamente banidas da existência coletiva por mais de um século de explicações sociais" (Latour, 2012, p. 105).

Entre as concepções fundamentais da vida percebida a partir da lógica da encruzilhada, está a característica de que

[...] os empreendimentos da vida também são percebidos como caminhos: realizar-se profissionalmente, ter sucesso escolar, fazer um bom casamento. As linhas de vida devem ser mantidas livres de obstruçáo espiritual. Muito além de uma simples metáfora entre a vida e caminhos, temos, creio eu, um pensamento que faz da vida um território (Anjos, 2006, p. 19).

A encruzilhada enquanto território onde os caminhos se cruzam, se abrem ou se fecham (Anjos, 2006), também evoca sentidos de fluidez, movimentos, misturas, encontros, trocas, rupturas, continuidades e dinamicidade (Barbosa Neto, 2012). Todo ponto de encontro de elementos de diferentes naturezas em prol de determinados objetivos do povo de santo são formas de encruzilhadas, que conformam um modelo cartográfico pelo qual é traduzido todo movimento das dimensôes que configuram o cosmos (Anjos, 2006).

A divindade Exu nos contextos de terreiros de diferentes matrizes onde é cultuado, emerge como protagonista elementar para mediar a cosmopolítica das encruzilhadas. É comum que muitos templos iniciem seus ritos com preces e oferendas a algum Exu. Exu é senhor das encruzilhadas, mediador da humanidade com os demais Orixás, cuja agência cosmopolítica é processada para que os caminhos dos participantes sejam abertos, trazendo segurança e boa fluidez energética nos diversos caminhos e linhas que se entrecruzam durante os trabalhos ${ }^{8}$ de um templo (Anjos, 2006). Os significados e associações de Exu são colocados neste artigo como substanciais para entender

8 Os trabalhos são quaisquer atividades que envolvem a mobilização dos Orixás, desde rezas, giras (sessóes espirituais), incorporaçóes, feitiços e oferendas para diversas finalidades.

Debates do NER, Porto Alegre, ANo 20, N. 37, P. 95-I 24, JAN./JUl. 2020 
a lógica da encruzilhada atrelada ao terreiro investigado, onde é actante nuclear e artesão de todas as relações.

Neste trabalho a cosmopolítica é compreendida como a relação entre humanos e não humanos (espíritos, vegetais, animais, elementos diversos) configurados num cosmos diferente daquele que é feito um objeto pelos cientistas modernos, a partir da coexistência de diversos seres, potencias cósmicas, práticas e mundos, que se conectam e se articulam por normativas e jurisdiçóes êmicas (Stengers, 1997). No que tange a cosmopolítica da religiosidade afro-brasileira, os trabalhos de Anjos (2006), Anjos e Oro (2009) e Ramos $(2015,2016)$ evocam este debate, ilustrando a política cósmica que eclode nos agenciamentos e conceitos êmicos em diferentes terreiros e situaçôes vivenciadas. Vale ressaltar que nas cosmopolíticas dos terreiros "se explora uma concepção de pessoa que se pode contrapor à noção usual de sujeito político que emana da modernidade política ocidental, concepção de pessoa essa estritamente vinculada ao modo afro-brasileiro de trabalhar as diferenças" (Anjos, 2006, p. 23).

Alicerçados nos suportes teóricos da Teoria Ator-Rede (Latour, 1994, 2004, 2012), que se mostra aberta para que seus conceitos e ferramentas sejam empregados no estudo etnográfico das religióes afro-brasileiras, apresentamos a abordagem em redes como uma cartografia das relaçóes entre humanos e não humanos, que conecta a natureza das coisas ao contexto destas, sem reduzir qualquer uma delas. Assim, a rede emerge como conceito e instrumento teórico-metodológico que possibilita desvelar o que é oculto, uma rede "é real como a natureza, narrada como o discurso e coletiva como a sociedade” (Latour, 1994, p. 12), não é estática, apenas é possível compreendê-la em seus processos de movimento.

É de suma importância ressaltar que as formas dos agenciamentos cosmopolíticos nas religiôes afro-brasileiras variam de acordo com o modelo etno-litúrgico que um porta-voz da rede integra, porque estas religiões são expressas por um grande espectro de subdivisôes e tradiçóes diferentes. Mesmo os terreiros pertencentes a uma tradição mágico-religiosa específica, apresentam divergências e idiossincrasia nas práticas, normativas, nomencla- 
turas liturgias e diversos modos de conceber o cosmos entre si, pois, "cada casa é um caso" (Barbosa Neto, 2012, p. 23) e, conceitos e atividades que são substanciais para alguns, podem ser secundários ou inexistentes para outros, assim, cada terreiro é um núcleo que reproduz de modo singular a rede da religiosidade afro-brasileira (Barbosa Neto, 2012). Desta forma, as informaçóes etnográficas registradas são válidas apenas ao terreiro investigado, apesar de existirem semelhanças entre os diversos templos.

Para que as agências que permeiam as encruzilhadas destas religiôes sejam compreendidas na complexidade que lhes são inerentes, é necessário que as subjetividades e relaçóes de poder - que são marginalizadas e ignoradas por discursos hegemônicos - sejam evidenciadas nos detalhes que eclodem em determinado local de culto. Assim, propomos partir da etnografia para seguirmos fidedignamente o que os actantes porta-vozes desta rede falam e fazem, a partir da observaçáo participante junto a um terreiro, com o objetivo de analisar as encruzilhadas conformadas pela sua rede de actantes nas inter-relações entre humanos, divindades e natureza, entendendo-as como operaçóes cosmopolíticas, mapeando os actantes e descrevendo os saberes mobilizados nas observaçóes. Para que os actantes de determinado grupo e suas inter-relaçóes sejam mapeadas, é necessário que existam porta-vozes do grupo em questão (Latour, 2004). As ações dos porta-vozes, mediadores e actantes em geral, emergem como nós que se conectam e conformam as encruzilhadas do agregado social (Latour, 2012).

O terreiro investigado neste trabalho é identificado como Abaça de Oxalá, localizado espacialmente no município de Pato Branco-PR ${ }^{9}$, no qual se encontra a conjunção interdependente e híbrida de fundamentos e práticas de Quimbanda e Umbanda cruzada com Candomblé (nação nagô), o culto também é identificado pelos interlocutores pelas categorias de Macumba ou Espiritismo, à qual é amplamente utilizada nas mais diversas situaçóes. A categoria de Espiritismo também foi observada na identificação litúrgica

9 O município possui 72.390 habitantes, ocupa 539,029 $\mathrm{km}^{2}$ e fica a uma distância de 433,53 km da capital Curitiba (IBGE, 2010).

Debates do NER, Porto Alegre, Ano 20, N. 37, P. 95-I 24, JAn./Jul. 2020 
por mães de santo e pais de santo de Umbanda, Batuque e Candomblé (nação kêtu-jeje) na Região Sudoeste do Paraná, registrados em entrevistas de outras pesquisas do autor com esta população (Favaro, 2018, 2015). Os porta-vozes do Abaça de Oxalá identificam o Espiritismo kardecista como "Espiritismo de mesa branca" ou "Espiritismo de Alan Kardec", cujos termos lhe diferenciam da categoria de Espiritismo, a qual é empregada para identificar qualquer manifestação religiosa afro-brasileira. Nesta conjuntura, é pertinente salientar que o termo Espiritismo é utilizado no texto se referindo ao culto que eclode no Abaça de Oxalá, tal como fazem seus porta-vozes, e não possui analogia com o Espiritismo kardecista.

A pesquisa de campo de orientação etnográfica foi efetuada no Abaça de Oxalá, que teve seu início em maio de 2016, a partir do momento em que o pai de santo Aldacir, representante do terreiro, negro, de 45 anos, confirmou a disponibilidade para que o templo pelo qual zela, fosse foco de um estudo etnográfico, pelo qual actantes humanos e não humanos foram rastreados. Pai Aldacir afirma que há mais de 20 anos é praticante do Espiritismo, e que há 10 anos atende a população com consultas e trabalhos em seu terreiro. Por meio da observação participante, as informaçóes da pesquisa de campo foram nutridas até março de $2020^{10}$, junto à participação semanal nas giras (sessóes espirituais), conversas informais com a comunidade que se agrega ao local, consultas privadas, acompanhamento e observação de trabalhos diversos realizados pelo Pai Aldacir aos consulentes, como por exemplo, aberturas de caminhos, quebras de demandas (magias negativas), exorcismos, auxílio em confecçóes de assentamentos ${ }^{11}$ e matanças $^{12}$, dentre outros ritos

${ }^{10}$ Houve interrupção das atividades do terreiro a partir deste período em razão da pandemia do covid-19, impossibilitando qualquer contato presencial para continuidade da pesquisa de campo.

${ }^{11}$ Em geral os assentamentos são formados pela confecção de uma variedade de elementos litúrgicos particulares de cada Orixá, terras e pedras de pontos-de-força (lugares sagrados), iconografias, integrados num vaso de argila ou ferro.

12 Sacrifício litúrgico de animais. No Abaça de Oxalá são sacrificados galos e galinhas, bodes e cabritas. 
efetivados no terreiro, ou, nos pontos-de-força (lugares sagrados externos ao terreiro). Desde o primeiro ano de convivência do pesquisador no terreiro ocorreu a integraçáo do mesmo junto à corrente (corpo de membros do terreiro $^{13}$, fato que viabilizou o registro e análise de informaçóes em um nível de profundidade que seria inacessível de modo externo.

Também são porta-vozes desta pesquisa os humanos vinculados à corrente do terreiro, bem como, os Orixás do pai de santo e dos médiuns enquanto "montados" em seus cavalos ${ }^{14}$, os quais conversavam com os consulentes, explicavam situaçôes e realizavam diversos trabalhos. Todos os eventos presenciados foram registrados em diários de campo, notas, fotografias, e analisados etnograficamente. Vale ressaltar que foram empregados nomes fictícios para identificação dos actantes humanos que emergem no decorrer do texto, com exceção do Pai Aldacir e Cambone Iva, pelo fato de serem representantes no local perante a sociedade civil. Os interlocutores acadêmicos e autores umbandistas e quimbandeiros que divulgam informaçóes sobre religiosidades afro-brasileiras também foram tomados como porta-vozes desta investigação dentro do escopo enunciado.

\section{TRADUZINDO AS LINHAS DE UMA REDE SÓCIO-CÓSMICA}

O Espiritismo conforme observado no contexto etnográfico, se mostra como uma grande organização sócio-cósmica, fundamentada nas relações entre Orixás e humanos, com o objetivo de aprimoramento da humanidade a partir das agências cosmopolíticas operadas nos terreiros. A experiência e observação de campo junto ao terreiro Abaça de Oxalá, permitiu averiguar que os Orixás estấo conectados em todas as relaçóes em que os conhecimentos e práticas percorrem na rede investigada.

${ }^{13}$ A corrente conta com seis médiuns de incorporação e três cambones. Os cambones servem os Orixás quando incorporados, registram seus comunicados e traduzem suas expressóes verbais êmicas.

${ }^{14}$ Categoria empregada para designar o médium que as entidades incorporam/montam.

Debates do NER, Porto Alegre, Ano 20, N. 37, P. 95-I 24, JAn./Jul. 2020 
Apesar do termo Orixá apontar uma influência africana em sua etimologia, no Abaça de Oxalá as entidades espirituais identificadas nesta categoria não são estanques ao contexto das narrativas de matriz nagô (mesmo mantendo mais de uma dezena destes - com seus respectivos desdobramentos - no interior do culto). Na cosmologia que subsidia as práticas do templo, os Orixás são espíritos humanos de alta graduação espiritual, que foram escolhidos e incumbidos por Oxalá ${ }^{15}$, para socializarem seus potenciais desenvolvidos nos ciclos reencarnatórios para com a humanidade.

Se um espírito carrega o título de Orixá consigo, significa que o mesmo é detentor de um ofício de suma importância para a manutenção da dinâmica sócio-cósmica, e também, exerce posto de liderança frente às legiốes de espíritos que se aperfeiçoam no Espiritismo. São actantes que governam territórios da vida humana e do cosmos, se cruzam em ambos e se mostram com formas híbridas, que destacam a pluralidade de ser na religiosidade afro-brasileira.

A categoria de encruzilhada que baliza estas associaçóes remete a concepçáo da multiplicidade, pois não há espaço para a existência de uma separaçáa ontológica entre sujeito e objeto (Ramos, 2015). O cosmos entendido pela lógica da encruzilhada denota o cruzamento do universo sagrado e concreto, tudo o que existe no mundo biofísico, também existe no mundo sobrenatural (Anjos, 2006). Ela permite que as marcas litúrgicas dos territórios revelem traços de uma cartografia do cosmos, que orienta a tradução da realidade no cotidiano dos iniciados, em associaçốes nas quais o cosmos e a natureza penetram repletos de sentidos nas relaçóes que os humanos fazem cotidianamente, imprimindo uma ampla rede de política cósmica que é acionada mediante saberes e normativas peculiares.

15 Orixá supremo, os mitos apontam que este é o Orixá primogênito de toda a criação e a ele, Olorum (o Deus supremo) incumbiu a tarefa de criação do mundo e todas as coisas nele existentes. Este Orixá é responsável por toda a vida e existência terrena. É identificado com o céu e suas virtudes vinculadas a sabedoria e equilíbrio (Berkenbrock, 1997).

Debates do NER, Porto Alegre, ano 20, N. 37, P. 95-I24, Jan./Jul. 2020 
Tal como aponta Ramos (2015) existem conexões e fluxos entre seres humanos (com seus anseios, culturas, situações e sentidos), pontos-de-força (florestas, oceanos, rios, encruzilhadas, cemitérios, campinas, pântanos, etc.) com seus elementos (minerais, vegetais, animais) e espíritos (Orixás e eguns ${ }^{16}$ ) que constituem uma fisionomia religiosa, política e espacial-temporal. A encruzilhada onde as conexôes e fluxos entre territórios distintos se cruzam é movimentada por meio do axé, ou, energia, que é a força cósmica invisível que permeia e vivifica todos os componentes materiais do cosmos, cara a todos os coletivos religiosos de matriz africana (Augras, 1983; Anjos; Oro, 2009). O axélenergia se trata do poder dos Orixás, responsável por cruzar os elementos existentes no mundo biofísico às suas naturezas espirituais, contudo, ele não é homogêneo, pois, o Espiritismo tal como investigado em campo, denota que existem múltiplas formas de axé, que são categorizadas em consonância direta com as qualidades dos Orixás.

A interpretação dos componentes do cosmos se dá a partir da compreensão de que cada elemento existente pertence ${ }^{17}$ a um ou mais Orixás, de acordo com o tipo de axé que é carregada consigo. $\mathrm{O}$ adepto aprende a identificar quais Orixás conectam os elementos deslocados nos agenciamentos cosmopolíticos, pelos quais o mundo passa a ser traduzido pelo relacionamento de diferentes irradiaçôes ${ }^{18}$ (ou vibraçóes). Os territórios identificados como pontos-de-força bem como todos os elementos tangíveis e intangíveis ali presentes, pertencem aos Orixás, as encruzilhadas pertencem a Exu e Ogum, as calungas (cemitérios) pertencem a Omulu, as matas (florestas e bosques) pertencem a Oxóssi, as pedreiras pertencem a Xangô, os rios pertencem à Oxum e os mares à Yemanjá; os pântanos e lagos pertencem à Naná Buruquê. Os

${ }^{16}$ Um egun é um espírito humano que não possui um ofício na dinâmica sócio-cósmica tal como um Orixá. Eguns também são análogos à categoria de almas.

${ }^{17}$ Ramos (2015) em sua tese de doutorado concernente à cosmopolítica da linha cruzada num terreiro em Mostardas-RS, também averiguou o uso da mesma categoria.

18 Termo para denominar a movimentação de um axélenergia em determinado corpo material, fenômeno, acontecimento ou local. 
pontos-de-força são como portais-encruzilhadas onde os adeptos buscam os poderes dos Orixás nos axés estendidos a todos os componentes do local, permeados por complexas e concentradas relaçóes ecológicas e cosmológicas, onde os Orixás habitam e governam.

Os Orixás se tornam cruzados/híbridos com diversos aspectos do ponto-de-força que lhes pertence, seja em nível de representação iconográfica, modo de culto e trabalhos de seus ofícios sócio-cósmicos. Por exemplo, comumente os Exus da linha dos Caveiras, que trabalham nas calungas, que é uma encruzilhada da vida e da morte tal como reitera Anjos (2006), são retratados com aparências degenerativas que remetem a morte e seu processo de decomposição da matéria, e assim, são ilustrados nas formas de caveiras e esqueletos (Figura 1), muitas vezes cercados de ossos e caixóes. São muitos Exus e Pomba-giras que pertencem a cada linha, sendo que a linha dos Caveiras é composta por Exu Caveira, Exu Doutor Caveira (ou Sete Caveiras), Exu Tata Caveira, Exu João Caveira, Exu Sete Catacumbas, Exu Meia-Noite, dentre outros. Estes Exus são responsáveis pelo encaminhamento das almas daqueles que recém realizam a passagem (a morte), e assim, também são muito solicitados em trabalhos que envolvem o afastamento de eguns sofredores e perniciosos. 
Figura 1 - Ponto de firmação de Exu Tata Caveira e da linha dos Caveiras no recinto doméstico do filho de santo Samael

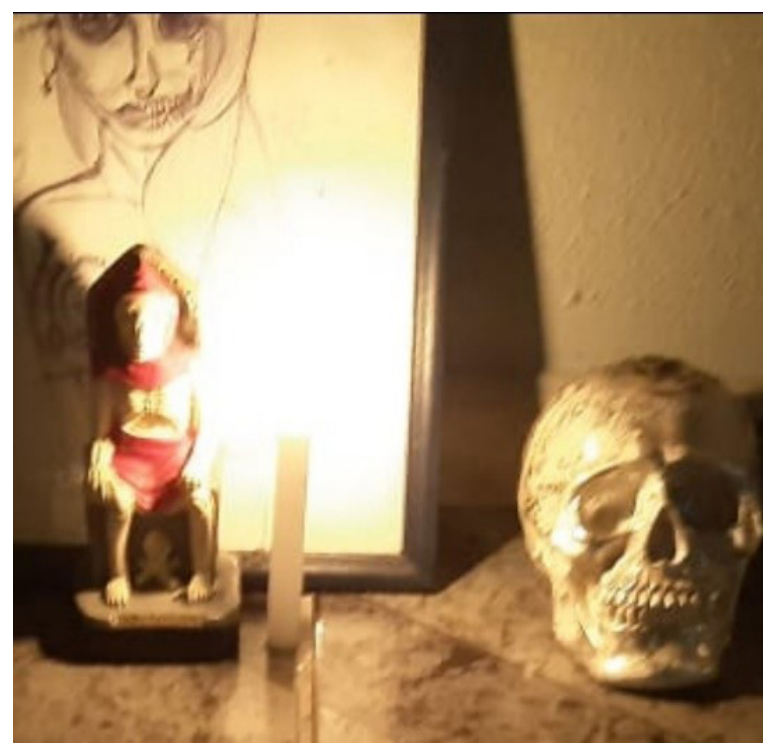

Fonte: Acervo do médium Samael (2020).

As Yemanjás e suas sereias, que habitam os mares, são retratadas em alguns momentos em aspectos teriomórficos na figura da sereia, metade mulher, metade peixe, que demonstra a grande conexão destas entidades com os seres marinhos, tal como relata a filha de santo Esmeralda em sua experiência onírica: "Eu estava com pessoas que gosto muito, admirando a praia e ouvindo o balanço das ondas, aí apareceu uma sereia que só cantava [...] minha Yemanjá quando vem em terra [incorporação] só canta” (Filha de santo Esmeralda, 2019).

A filha de santo Ana, ao relatar as visóes oníricas da Pomba-gira Figueira, retrata a mesma como uma mulher toda vestida de preto, rodeada eguns que ela comanda, numa região astral umbralina de cor cinzenta e vermelha opaca, em baixo de uma grande figueira - que é o território no qual tal entidade exerce domínios. A filha de santo Yasmin ao relatar as experiências oníricas com a Cabocla Jurema alega que a mesma apareceu em forma de 
onça pintada em meio às matas - que é o território que lhe pertence, junto a Oxóssi e todos os Caboclos. Cada ponto-de-força tem sua idiossincrasia de axés, permitindo uma multiplicidade de feiçóes e comportamentos peculiares dos espíritos que compóem as falanges das linhas do Espiritismo.

Nesta conjuntura, pode-se averiguar que a aglutinação e cruzamentos de determinados traços que eclodem em pontos-de-força e/ou territórios oníricos permite interpretar as formas e corpos percebidos pelos iniciados "de acordo com um arcabouço preceptivo" (Anjos, 2006, p. 86), exclusivos aos integrantes da corrente do templo que concebem tais territórios com seus imaginários e experiências sobrenaturais. As experiências de sonhar com sereias, figueira, onça, dentre outros seres associados ao panteão cultuado no terreiro "em outro lugar, um outro ethos deixaria escapar sem forma e sem nome o mesmo conjunto de traços" (Anjos, 2006, p. 86), ou, seriam interpretados com outro arcabouço preceptivo. A encruzilhada enquanto perspectiva ontológica prolifera estas formas híbridas dos poderes que regem o cosmos do povo de santo investigado.

Os Orixás são indissociáveis dos actantes que arrastam consigo por meio do axé, tais como os pontos-de-força e seus elementos. A forma que os Orixás são catalogados, identificados e entendidos se dá por meio do conceito de linha, assim temos a nominação de diversas linhas por quais os Orixás se agrupam, tais como linha da encruzilhada, linha das almas, linha das matas, linha das águas, etc., as quais possuem polaridades onde os actantes espirituais se agrupam, que são identificadas em linha da esquerda (ou Quimbanda), onde se agregam Exus e Pomba-giras, que trazem sentidos de transformação e movimento, e linha da direita (ou Umbanda), onde se agregam Orixás nagôs, Pretos-velhos (ancestrais negros anciãos) e Caboclos (ancestrais indígenas), que trazem sentidos de conservação da ordem e das virtuosidades do templo. Estas diferentes linhas sistematizadas e organizadas em falanges de espíritos que compóem o Espiritismo são componentes de uma política cósmica que arrasta conexôes de seres humanos com deuses e suas constelações de elementos e agências mágico-religiosas. 
Cada linha conecta uma esfera de existência específica, na qual legióes de espíritos são agrupadas em diversas outras linhas e sublinhas de acordo com os atributos congêneres que compartilham e desempenham nesta esfera. Deste modo, a linha das almas, por exemplo, que agrega os axés inerentes à relação da sociedade com a calunga, tem como potências cósmicas expoentes Obaluaê (Orixá responsável pelos mortos) em sua linha da direita, e Exu Caveira em sua linha da esquerda. A linha das almas tal como outras linhas, pode se dividir em diversas sublinhas que denotam concentraçóes de axés e domínios específicos (linha do cruzeiro das almas, linha da encruzilhada da calunga, linha das catacumbas), que terão seus representantes na linha da direita, tais como Iansã de Balé, Ogum Megê, Pretos-velhos da linha das almas, dentre outros, e na linha da esquerda, tais como Exu Tata Caveira, Pomba-gira Rosa-Caveira, Pomba-gira das Almas, etc.

Neste sentido, a linha em que cada Orixá é conectado, é também uma encruzilhada, na qual espíritos, lugares, natureza, oferendas, significados e liturgias são arregimentados, associados e reunidos mediante a similaridade do tipo de axé imanente aos mesmos, o qual baliza o tratamento litúrgico que os actantes hão de receber, permitindo a observação de diferenciaçóes nos variados níveis da rede do coletivo pesquisado. Por exemplo, o Exu Tata Caveira, que pertence à linha das almas na linha da esquerda, possui comportamentos, funçóes e ações que dizem respeito ao ponto-de-força da calunga, à linha de Quimbanda, e à sublinha dos Caveiras, sendo responsável pelo fluxo de almas recém desencarnadas para dentro da calunga. Pai Aldacir ensinou que Exus da linha das almas, apreciam libaçóes na porta da calunga, no cruzeiro das almas, nos túmulos; velas e objetos de cores preta, branca, vermelha, amarela ou lilás; o conhaque é o predileto entre as bebidas fortes; seus padês (farofas) devem ser elaborados com farinha de mandioca. Por pertencer à linha dos Caveiras, este Exu também aprecia oferendas com ossos e carne crua, que se trata de um capricho singular desta linha.

As linhas e seus Orixás são acionadas de acordo com o interessamento de humanos que recorrem às consultas com os Exus ou Pomba-giras incorporados no Pai Aldacir, os quais fornecem diagnósticos espirituais para 
serem tratados por meio de trabalhos. De acordo com Callon (1986) o conceito de interessamento exprime os dispositivos que geram a conexão entre os actantes humanos e não humanos na rede, que no terreiro puderam ser averiguados pelo trânsito de consulentes (filhos de santo e clientes) que movimentam a rede para resolução de questôes afetivas, financeiras, da saúde, desenvolvimento da espiritualidade, descarrego de energias perniciosas, dentre outros. Cada situação de consulta cruza os domínios do plano físico e espiritual, gerando um diagnóstico e tratamento específico que não pode ser extrapolado para outro consulente. No momento da consulta, o Orixá incorporado corre gira ${ }^{19}$ e traduz o que a rede de Orixás que lhe acompanha recomenda ao consulente.

Por exemplo, numa ocasião em que o consulente era perturbado por eguns, o Exu Sete Ventanias do Pai Aldacir correu gira e informou que havia solicitação de três Orixás da linha das almas para resolver o problema, e decidiu que o trabalho seria endereçado ao Orixá Omulu em seu assentamento, onde seria necessário um galo, que foi sacrificado sobre as oferendas que consistiam em doboru (pipocas), padê de farinha de mandioca com dendê, mel, vinho tinto, charuto, folhas de mamona e um colar de contas branco para ser cruzado com o axé de Omulu para proteção do indivíduo (Figura 2). A execução do trabalho, com seus elementos litúrgicos, junto ao assentamento, cujo interior contém axés que acionam a linha das almas (terra de calunga, búzios, dentre outros) a partir de Omulu, exprime uma agência cosmopolítica numa encruzilhada onde as almas perturbadoras são desterritorializadas do caminho do indivíduo e encaminhadas para a calunga para the territorializar caminhos seguros e de bem-estar.

${ }^{19}$ Termo que sinaliza a comunicação do Orixá incorporado com outro Orixá que está no mundo espiritual durante o processo da consulta, numa espécie de reunião e negociaçáo cósmica.

Debates do NER, Porto Alegre, ano 20, N. 37, P. 95-I 24, JAN./Jul. 2020 
Figura 2 - Trabalho de afastamento de eguns endereçado para Omulu diante de seu assentamento no Abaça de Oxalá

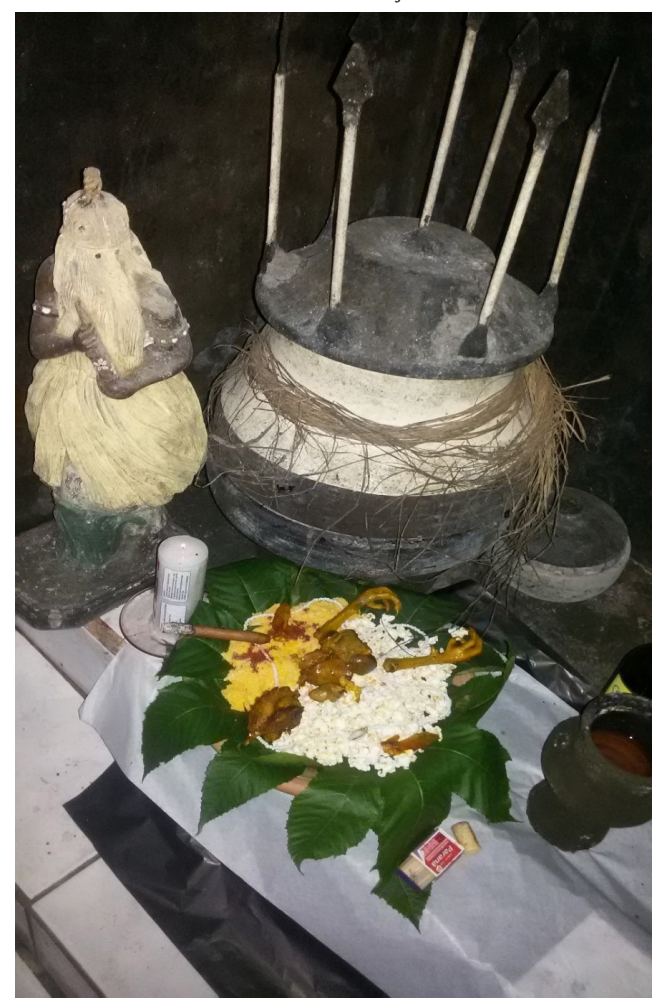

Fonte: Acervo de Jean Filipe Favaro (2017).

O panteão do terreiro pesquisado perpassa todos os níveis existenciais de seus adeptos e conforma um amplo repertório de tradução com noções de valores, correspondências e significados dos axés que estão cristalizados em cada acontecimento, cor, fenômeno, local e elemento deslocado liturgicamente. Cada concepção e atividade mágico-religiosa realizada é expressa como uma nova encruzilhada na rede sócio-cósmica, que conecta Orixás, linhas, axés, humanos, desejos, situações micros-sociais, lugares, naturezas e elementos variados numa reunião cósmica com a finalidade de trazer aberturas para os caminhos da vida seguirem sem obstrução. Percebe-se 
que a política cósmica dos Orixás eclode a partir de necessidades humanas, conhecimentos, práticas e relaçóes complexas com diversidade de detalhes, formas e conexôes, que viabilizam sentir, pensar e experimentar a existência numa posição epistêmica onde existe continuidade do mundo humano, com o mundo dos deuses e a natureza.

\section{ASSENTAMENTO DE EXU: FUNDAMENTO E LEGITIMAÇÃO DE UMA ENCRUZILHADA MULTIDIMENSIONAL}

Os diferentes caminhos, formas, lógicas, informaçôes, não importa quão distante ou assimilares sejam, ao se encontrarem nas encruzilhadas de Exu, se cruzam e hibridizam seguindo como pluralidades de complexas relaçôes e não como uma unidade que apenas se fundiu numa "colcha de retalhos" (Anjos, 2006). As encruzilhadas percorrem todos os níveis da vida dos adeptos, neste particular, Exu é situado num ofício de suma importância para movimentação, conexóes e desconexôes dos actantes e suas diferenças dentro da comunidade sócio-cósmica do Espiritismo do terreiro investigado, para avançarmos numa compreensão mais clara concernente a tal rede, suas encruzilhadas e operaçốes cosmopolíticas, se faz necessário maior detalhamento ao respeito da divindade Exu, que também é uma linha na qual se arregimentam legiôes de espíritos sob tal nomenclatura, que agem de modo similar com diversas peculiaridades.

Exu, o trickster nagô, senhor das encruzilhadas, no contexto do Espiritismo enunciado, emerge como uma categoria coletiva de espíritos (Exus quando masculinos e Pomba-giras quando femininos) alocados ao grande zoneamento cósmico-mítico da linha de Quimbanda, ou linha de esquerda, onde emergem como autoridades máximas nas regiôes próximas do plano material e aspectos instintivos dos seres humanos. Exu é divindade da comunicaçáo, é tradutor, desempenha a incumbência de interprete dos deuses aos seres humanos e vice-versa. "Ser intérprete, no sentido em que Exu o é, significa aceitar a parcialidade das visóes das coisas e dos seres que entram 
em contato" (Silva, 2015, p. 107). Ele se vale da fala e da língua, como um veículo de transmitir verdades ou mentiras, destarte, é guardião das informaçôes que circulam nas vias que conectam o mundo espiritual e o mundo físico (Silva, 2015). Apenas desloca as informaçóes entre estes mundos se lhe prestarem as devidas libaçóes, por isto, Exu sempre é o primeiro a receber oferendas antes de qualquer operação ritualística, para assegurar fluidez entre os mundos de diferentes níveis existenciais no local e momento em que eclode um ritual afro-brasileiro (Prandi, 1994). Assim, a figura de Exu evoca a tensão presente nas barganhas entre diferentes mundos, viabilizada pelas oferendas (Silva, 2015).

As iconografias dos Exus e Pomba-giras, cujas estatuetas podem apresentar entrecruzamentos e formas híbridas de homens e mulheres com animais, muitas vezes desnudadas, de feiçóes eróticas, náo impóem nenhum tipo de padrão de humanidade ideal - como acontece na representaçấo da linha da direita, na qual o modelo dos santos católicos é o ideal para representar a espiritualidade. A manifestação dos Exus e Pomba-giras é o ápice da subversão do regime cristáo de representaçáo do sagrado, que expressa uma subjetividade que perdeu a interioridade (Anjos, 2006).

Quando incorporados nos médiuns (Figura 3), num momento em que existe o hibridismo e entrecruzamento da entidade com o corpo e consciência do médium, cada Exu apresenta seus caprichos singularizantes, apesar de apresentarem similaridades, tal como o uso de capas, cartolas/chapéus, bengalas, geralmente das cores vermelhas e pretas, fumam charutos, dão gargalhadas, bebem marafo (cachaça), uísque, conhaque, vinhos, cervejas e licores. As Pomba-giras quando incorporadas, em geral vestem saias ou vestidos, cobrem a cabeça com chapéu, ou lenço, algumas também vestem capa, das cores vermelhas e pretas, utilizam leques, perfumes, joias e bijuterias, fumam cigarros finos ou cigarrilhas, bebem principalmente champanhe e licores, porém também podem beber marafo e bebidas fortes dependo da situação peculiar. 
Figura 3 - Fotografia de Exu Tranca-Ruas do Pai Aldacir durante momento de incorporação

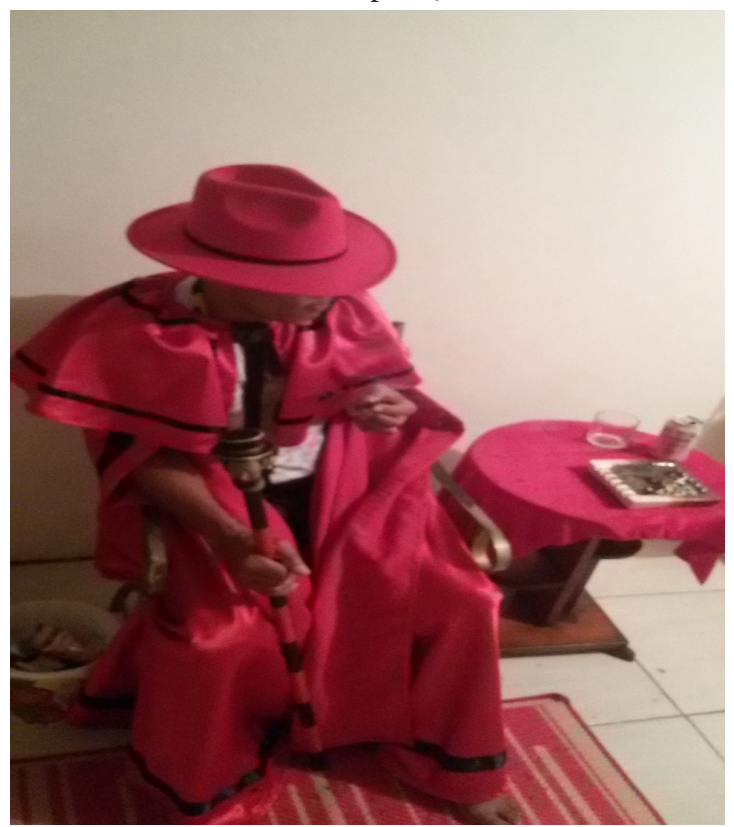

Fonte: Acervo de Jean Filipe Favaro (2016).

As libações prestadas pelos humanos para acionarem os Exus e toda rede que arrastam consigo, em geral são constituídas de velas pretas, vermelhas, vermelho-pretas e brancas, padê de farinha de milho ou mandioca com epô (azeite de dênde), marafo, mel, melado, açúcar mascavo, ou água, charutos, cigarrilhas, cigarros finos, bebidas diversas, pipocas, cravos e rosas vermelhas, folhas de mamona, bananeira e limoeiro, frutas cítricas, pimentas, colocadas sobre alguidares, quartinhas e toalhas (ou papel seda) vermelhas e pretas, carnes e vísceras bovinas, suínas, caprinas e de aves assadas ou cruas. Suas saudaçóes são Laroyê, Mojubá e Alupandê. A menga (sangue) de galos, galinhas, bodes e cabritas sacrificados ritualisticamente, são suas oferendas prediletas, pois a menga é vida, que os mobiliza com maior potência no mundo físico, e atua como um actante de suma-importância nos rituais de

Debates do NER, Porto Alegre, ANo 20, N. 37, P. 95-I 24, JAN./JUl. 2020 
assentamento de Exu/Pomba-gira. Vale ressaltar que a cor do animal varia de acordo com a necessidade do ritual e das particularidades da entidade, por exemplo, os Exus da linha das almas tem a preferência por animais das cores branca e preta, já os Exus da linha da encruzilhada têm preferência por animais de tonalidades avermelhadas.

Os Exus deslocam atributos que remetem à dinâmica da vida, às mudanças, às passagens e caminhos. Sáo eles que abrem e fecham todos os caminhos para que os axés sejam percorridos pelos diferentes mundos e realidades, viabilizando que os demais Orixás se aproximem dos seres humanos (Anjos, 2006). "Nessa cosmologia, o Exu situa-se no começo de todo processo de agenciamento da subjetividade afro-brasileira" (Anjos, 2006, p. 17). Ele (Exu) é o primeiro, pois é o princípio da natureza que coloca todas as coisas em movimento, o qual deve estar consonante com os intentos subjetivos dos adeptos e consulentes. Assim, é no modelo espaço-temporal encruzilhada de Exu na linha da esquerda que iniciam e se realizam todos os planos e atividades dos humanos. De acordo com Anjos (2006) esta racionalidade extrapola os significados de uma simples metáfora entre a vida e os caminhos, pois traz uma concepçáo de mundo que faz da vida um território, sintetizando neste modelo o início de toda espécie de agenciamento operada pelo religioso afro-brasileiro.

A argumentação de que Exu emerge como princípio de todo agenciamento e subjetividade é robustecida com as afirmaçôes do Pai Aldacir, nas quais alega que um terreiro de sua tradição apenas pode ser fundado após o assentamento do Exu pai de cabeça ou Pomba-gira mãe de cabeça do médium desenvolvido, tal como afirma: "Primeiro assentar Exu chefe da casa, não precisa ter assentamentos para todos, ao menos que o Orixá peça. $\mathrm{O}$ assentamento é um compromisso do chefe (Exu/Pomba-gira) com o terreiro, e ele responde pela sua cabeça e pelo terreiro" (Pai Aldacir, 2017).

$\mathrm{O}$ assentamento de Exu se trata do núcleo do terreiro, agindo como uma rede, uma encruzilhada e organismo multidimensional, a partir do qual as atividades do terreiro obtém legitimidade espiritual, segurança energética e compromisso da entidade assentada com o iniciado, que se torna sacerdote 
a partir da confecçáo do assentamento. Um assentamento nos termos apresentados é um contrato/pacto entre a entidade com o pai de santo e vice-versa, no qual ambos estáo indissociavelmente conectados, onde o sacerdote deve depositar diante do assentamento libaçôes semanais e mensais com o objetivo de nutrir o Orixá, que lhe retribuirá concedendo eficácia e segurança em todas as atividades do terreiro, mesmo que tais atividades sejam direcionadas a outro Orixá que não seja assentado.

Um assentamento de Exu de acordo com a tradição professada no Abaça de Oxalá é composto por um arranjo de actantes não humanos, como terra de calunga, terra de encruzilhadas, terra de matas, terra de bancos e comércios, jóias, ferros, tridentes, favas (sementes), otáslokutás (pedras), moedas correntes e antigas, punhais, iconografias, dentre outros elementos cuja maioria é secreta, que substancializam e potencializam as açóes do Exu, organizados num caldeiráo de barro, em conjunto com o sacrifício de um cabrito, cuja menga é parte derramada desde o ápice da cabeça do iniciado, e parte junto aos axés do animal (juntas das patas e cabeça) que sáo depositadas no interior do caldeiráo com demais componentes (Figura 4). $\mathrm{O}$ animal é sacrificado com a faca que o novo sacerdote empregará para suas matanças, tanto para a linha da esquerda, quanto para a linha da direita. Vale ressaltar que é a menga e os axés do animal que substancializam vida ao assentamento, que ativam os axés dos demais actantes presentes para se comportarem como rede que conecta com as demais linhas do Espiritismo, e também transmuta o iniciado em sacerdote desta tradição, que a partir do ritual se torna um porta-voz legítimo de Exu, dos Orixás, seus axés e linhas. 
Figura 4 - Fotografia do assentamento do Exu Sete Ventanias do Pai Aldacir com oferendas que o nutrem e direcionam

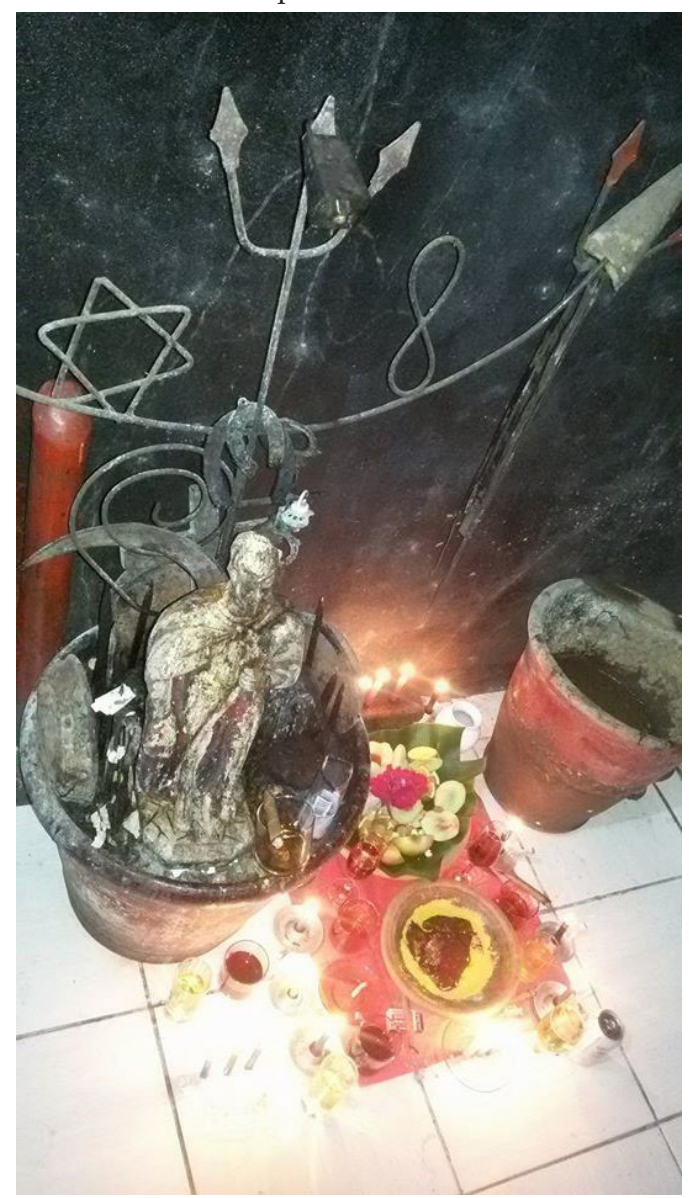

Fonte: Acervo de Jean Filipe Favaro (2018).

Quando estes elementos são aglutinados e ativados ritualisticamente, o vaso que contém a mistura de materiais passa a atuar como um poderoso dispositivo conector do indivíduo e do templo com um determinado Orixá, e passa a reproduzir condiçóes de força mágica/axélenergia em simetria aos pontos-de-força em que os elementos foram coletados, agindo como um 
ponto-de-força por excelência e como uma rede que exprime a plenitude da divindade com a conexão com todas as linhas que perpassam o Espiritismo, que filtra e direciona todo axé mobilizado pelos humanos integrantes da corrente do terreiro, tal como explicita muito bem o Pai Aldacir:

O assentamento substitui muitas vezes a ida na natureza, quem tem Orixá assentado não precisa ir sempre no cemitério, na mata, na encruzilhada, na campina ou no rio. Você vai até a natureza buscar ela, pega e assenta, você coloca ela num vaso, é a força da natureza que você coloca num vaso junto com o Orixá [...] Desde terra da encruzilhada, terra do cemitério, terra de delegacia, terra de banco, terra de hospital, terra de frente de loja, tudo o que precisar para fazer o trabalho, você tem naquele vaso assentado para o Orixá [especificamente em casos de assentamento de Exu]. Entáo você não precisa de repente, fazer um trabalho para tirar alguém da prisão, você náo precisa ir lá na frente da delegacia fazer esse trabalho, você tem a terra da delegacia naquele vaso, e naquele ponto-de-força do Orixá se faz um trabalho. E ali já tira a pessoa da cadeia, ou para curar alguém que está no hospital e não pode vir no terreiro, você faz ali. Então esse ponto-de-força gera energia que o Orixá encontra e consegue realizar o que é pedido para ele [...] Até você ter o Orixá assentado, entấo muitos dos trabalhos que você realizar, eu digo que você terá que buscar a natureza, buscar a campina, buscar a mata para realizar seus trabalhos, porque você está num ponto que é a natureza mesmo. Se você tem Orixá assentado, você trata, você faz o trabalho que você quiser, dentro do teu terreiro que não tem problema algum [...] Então para quem é da religião, sabe que o assentamento é vida, não é apenas um vaso cheio com coisas da natureza, e ali tem vida, e faz com que coisas aconteçam (Pai Aldacir, 2017).

Por meio de um assentamento a natureza em seus múltiplos arranjos é desterritorializada de seu local original e reterritorializada no ambiente do terreiro, permitindo uma conexão contínua dos humanos com os Orixás e natureza de modo seguro e eficaz, viabilizando a ação plena destas divindades. Cada elemento presente no assentamento é concebido como um portal, um fio conector para o Orixá atuar com proficuidade. O Orixá se conecta com diversos lugares, territórios, mundos e naturezas a partir de cada substância 
contida no vaso, pois em todos os lugares onde houver o determinado elemento, o Orixá poderá alcançar. Por exemplo, as observaçóes de campo reiteram em diversos momentos que a água do Orixá é indispensável em qualquer trabalho, pois "se não tiver a água do Orixá, quando ele estiver trabalhando e encontrar água no caminho, se a oferenda não tiver água, ele para porque não pode passar" (Pai Aldacir, 2016). Para que a atuação do Orixá seja ininterrupta, entre as libaçóes semanais que lhe nutrem, a água que é inserida numa quartinha deve ser continuamente renovada.

$\mathrm{O}$ vaso do assentamento ocupa função análoga à de um útero no qual o Orixá nasce para o mundo físico em conjunto com o novo sacerdote, numa microrreprodução da criação, onde se fazem necessários os materiais que correspondam com o Orixá, que agirão feito membros e órgãos de seu novo corpo físico, que também é um ponto-de-força, onde ele é cultuado (Coppini, 2016). A imprescindibilidade de assentar Exu está associada à abertura de caminhos, pois os Exus são guardiões de todas as encruzilhadas, e assim, ao serem assentados propiciam direcionamentos e concretizaçóes das atividades mágico-religiosas de um terreiro para toda rede de potências cósmicas, livres de obstruçóes negativas. $\mathrm{O}$ ato de assentar primeiramente Exu repercute noutras modalidades de ritos para quaisquer Orixás, os quais requerem que Exu obtenha a primazia das libaçóes efetuadas (mesmo que apenas uma vela), com o objetivo de abrir os caminhos para os demais Orixás trabalharem e removerem as energias indesejáveis do recinto no qual se efetiva o rito. Assim, Exu emerge como o agente principal na lógica da encruzilhada que cruza e configura qualquer início de ação, tal como expóe Anjos (2006) "se a encruzilhada é um ponto ambíguo na religiosidade afro-brasileira é certamente porque ali tanto pode ser o começo, a abertura de um fluxo, quanto o fim de um território existencial" (Anjos, 2006, p. 19).

A partir do assentamento de Exu, que é seu nascimento formalizado no plano material, o terreiro também nasce como uma encruzilhada multidimensional, com as condiçóes de reproduzir o axé existente nos pontos-de-força, efetivando trocas metabólicas entre as esferas da natureza, da sociedade e das divindades de modo ininterrupto e permeado de açóes concretas. Para 
o funcionamento desta encruzilhada junto às necessidades emergentes do local, é necessária grande quantidade de nutrientes específicos, que são os axés que contém cada elemento que é ofertado regularmente pelas libaçóes, movidas pelos variados interessamentos dos humanos que circundam o local. Esta encruzilhada, repleta de correspondências simbólicas, por meio de Exu como agente do deslocamento do axé, permite o trânsito e atuaçáo de múltiplos entes espirituais e humanos em diferentes níveis de organização da rede conformada pelos actantes.

Vale ressaltar que toda ação mobilizada no terreiro, arrasta de um modo ou de outro, o assentamento e sua rede subjacente. As observaçóes de campo demonstram que o Exu assentado, em seu hibridismo com o sacerdote do templo, é o cerne das operaçôes cosmopolíticas no terreiro, pois, as incorporaçôes e trabalhos dos mais variados Orixás ocorrem a partir das deliberaçôes do Exu-chefe da casa. Apesar do Pai Aldacir também incorporar ao início das giras Pretos-velhos e Caboclos (linha da direita), são os Exus/Pomba-giras incorporados que falam, ensinam e possibilitam o cruzamento dos axés e trabalhos que outros Orixás solicitam no plano astral.

\section{CONSIDERAÇÓES FINAIS}

A rede que perpassa a encruzilhada enquanto categoria êmica na religiosidade afro-brasileira tal como enunciada é destacada pelo acionamento de actantes humanos e não humanos (divindades, natureza, objetos, etc.) num constante porvir, pois não possui um fim, denotando incessantes aberturas para novas relaçôes que são configuradas de acordo com o movimento que cada actante mobiliza no tecido socio-cósmico. Deste modo, as encruzilhadas apresentadas se delineiam da forma descrita num primeiro nível de análise, que se aprofundado, diversas novas encruzilhadas e caminhos podem ser mapeados.

A Teoria Ator-Rede como abordagem que fundamentou o presente trabalho (Latour, 2012), permitiu seguir fidedignamente o que os porta-vozes 
falam e fazem, o que tornou possível descrever a existência de cada actante e seus territórios, como habitados por forças divinas, e denotou, de forma singular, um feixe de linhas convergentes e divergentes que conformam uma rede de interaçôes e informaçóes que conectam em volta de si e, a partir de si, diferentes estratos da existência (Augras, 1983), mobilizando consigo uma rede que arrasta um turbilhão de actantes. Esses podem se relacionar à medicina, culinária, rezas, palavras, fantasias, divindades e aspectos da natureza que são indissociáveis, viabilizando conexóes e fluxos entre os elementos de todo o sistema (Anjos, 2008; Ramos, 2015).

Entendendo a política enquanto correlações de forças e poderes, a categoria de axélenergia se mostrou substancial para o entendimento da cosmopolítica afro-brasileira, pela qual os intentos, imaginários, os animais, vegetais, minerais, lugares, corpos celestes, Orixás e espíritos diversos se conectam e se tornam revestidos de valores, vida, significados e poderes diversos, que são elementares para que sejam engendradas açóes concretas sobre a realidade. É por meio do axélenergia que se processa a lógica da encruzilhada e toda cosmopolítica associada, sendo os Orixás porta-vozes desta substância, e, Exu, senhor das encruzilhadas, mediador dos mundos, é o responsável pela sua dinâmica e movimentação. A concepção da realidade pelo repertório de traduçáo do axélenergia, em que cada elemento existente possui correlação com algum axé, Orixá e linha, viabiliza que os aspectos da natureza e do cosmos, que são ignorados e marginalizados pela lógica dualista cartesiana, sejam valorizados e participantes da sociedade em simetria aos humanos.

Os pontos-de-força, as experiências oníricas, as linhas, os trabalhos, os assentamentos, além de se tratarem de diferentes modos de agências cosmopolíticas que mobilizam múltiplos axés/energias, foram percebidos como formas de territórios-encruzilhadas de diferentes naturezas, cujas tramas sempre estão conectadas, de um modo ou outro, na grande rede do panteáo do terreiro, cruzando objetivos, interpretaçóes, situações, significados, elementos, Orixás, etc., em diferentes medidas e escalas num mesmo tempo-espaço. Cada território-encruzilhada quando acionado mobiliza uma diversidade de actantes, 
descentralizando os humanos do desenho cartográfico, apresentando uma democracia cósmica onde todos os participantes têm vozes, direitos e deveres em simetria uns aos outros (Latour, 2004). Percebe-se também que a configuração das agências cosmopolíticas é relativa e flexível à singularidade de cada situação que arrasta os atores-rede no agregado social investigado. Os axés/energias percorrem em todas as encruzilhadas mapeadas, vinculando e hibridizando as formas e açôes, pelas quais veiculam as informaçôes contidas na episteme averiguada.

O exemplo do assentamento de Exu como alicerce fundamental para inauguração de um terreiro, bem como, a descrição de seus mecanismos de funcionamento, numa perspectiva que extrapola as noçóes de fetichismo e meras representaçóes simbólicas, permite exprimir de modo sintético a dinâmica da lógica da encruzilhada. Pois o assentamento de Exu aglutina os pontos-de-força e seus elementos, os saberes e experiências acumuladas pelo adepto, libaçóes de diversos modos e finalidades e um Exu ou Pomba-gira que irá se conectar com todas as linhas do Espiritismo, para compor e assegurar com plenitude as atividades e encontros dos atores-rede no terreiro. Vale ressaltar que Exu é indissociável da encruzilhada e de sua lógica de funcionamento, sendo esta relação Exu-encruzilhada que media e inicia todo processo de subjetividade das agências cosmopolíticas analisadas.

A partir de tais descriçōes se torna evidente que a imaginação e seus produtos se tratam de dispositivos basilares e concretos para que a realidade seja transmutada junto às diversas linhas que compóem a política cósmica do Espiritismo do terreiro investigado. Assim, numa concepção alternativa do mundo junto aos métodos antropológicos consistentes, se torna possível conectar aquilo que é tido como "irracional" e marginal pela ordem dominante no meio científico - antes embebido de explicaçóes cientificistas e mecanicistas da sociedade e da natureza -, para evidenciar outras racionalidades. Deste modo, Exu como aquele que transgrede e subverte toda ordem posta, se apresenta protagonista de uma ontologia tâo complexa, emblemática e fluída quanto os atributos vinculados à sua figura, permitindo conceber 
o cosmos em dimensóes que extrapolam os sentidos que a mente dualista cartesiana é capaz de perceber.

\section{REFERENNCIAS}

ANJOS, José Carlos Gomes. A filosofia política da religiosidade afro-brasileira como patrimônio cultural africano. Debates do NER, Porto Alegre, v. 9, n. 13, p. 77-96, 2008.

ANJOS, José Carlos Gomes. No território da linha cruzada: a cosmopolítica afro-brasileira. Porto Alegre: Editora da UFRGS: Fundação Cultural Zumbi dos Palmares, 2006.

ANJOS, José Carlos Gomes dos; ORO, Ari Pedro. Festa de Nossa Senhora dos Navegantes em Porto Alegre: sincretismo entre Maria e Iemanjá. Porto Alegre: Secretaria Municipal de Cultura, 2009.

AUGRAS, Monique. O duplo e a metamorfose: a identidade mítica em comunidades nagô. Petrópolis: Vozes, 1983.

AUGRAS, Monique. Segunda-feira é das almas. Rio de Janeiro: Pallas, 2012. BARBOSA NETO, Edgar Rodrigues. A máquina do mundo: variaçóes sobre o politeísmo em coletivos afro-brasileiros. 2012. Tese (Doutorado em Antropologia Social) - Museu Nacional, Universidade Federal do Rio de Janeiro, Rio de Janeiro, 2012.

BASTIDE, Roger. As religióes africanas no Brasil: contribuiçôes a uma sociologia das interpenetrações de civilizações. Tradução de Maria Eloisa Capellato e Olívia Krähenbuhl. São Paulo: EDUSP, 1971. v. 1.

BERKENBROCK, Volney. A experiência dos orixás. Petrópolis: Vozes, 1997. CALLON, Michel. Some elements of a sociology of translation: domestication of the scallops and the fishermen of St Brieuc Bay. In: LAW, John (ed.). Power, action and belief: a new sociology of knowledge. London: Routledge \& Kegan Paul, 1986. 
COPPINI, Danilo. Quimbanda: o culto da chama vermelha e preta. 2. ed. [S. 1.]: Editora Capelobo, 2016.

FAVARO, Jean Filipe. A relação sociedadeldivindade/natureza no templo espirita de umbanda Abaça de Oxalá em Pato Branco-PR: modos plurais de existência. 2018. Dissertaçấo (Mestrado em Desenvolvimento Regional) Universidade Tecnológica Federal do Paraná, Pato Branco, 2018.

FAVARO, Jean Filipe. Etnobotânica dos cultos afro-brasileiros na Regiāo Sudoeste do Paraná: a importância das plantas na construção da identidade cultural. 2015. Trabalho de Conclusão de Curso (Graduação em Engenharia Florestal) - Universidade Tecnológica Federal do Paraná, Dois Vizinhos, 2015. FERRETTI, Sérgio. Repensando o sincretismo. 2. ed. São Paulo: Arché Editora, 2013.

INSTITUTO BRASILEIRO DE GEOGRAFIA E ESTATÍSTICA (IBGE). Características gerais da população, religiäo e pessoas com deficiência. Disponível em: https://ww2.ibge.gov.br/home/estatistica/populacao/censo2010/caracteristicas_religiao_deficiencia/caracteristicas_religiao_deficiencia_tab_uf_xls. shtm. Rio de Janeiro: IBGE, 2010. Acesso em: 14 ago. 2017.

LATOUR, Bruno. Jamais fomos modernos: ensaios de antropologia simétrica. São Paulo: Editora 34, 1994.

LATOUR, Bruno. Politicas da natureza: como fazer ciência na democracia. Bauru: EDUSC, 2004.

LATOUR, Bruno. Reagregando o social: uma introduçáo à teoria do ator-rede. Salvador: EDUFBA, 2012.

PRANDI, Reginaldo. Pombagira dos candomblés e umbandas e as faces inconfessas do Brasil. Revista Brasileira de Ciências Sociais, São Paulo, v. 9, n. 26, p. 91-102, 1994. 
RAMOS, João Daniel Dorneles. A (cosmo)lógica das relaçôes humano-animais nas religiōes afro-brasileiras. Iluminuras, Porto Alegre, v. 17, n. 42, p. 166-189, 2016.

RAMOS, João Daniel Dorneles. O cruzamento das linhas: aprontamento e cosmopolítica entre umbandistas em Mostardas, Rio Grande do Sul. 2015. Tese (Doutorado em Antropologia Social) - Universidade Federal do Rio Grande do Sul, Porto Alegre, 2015.

SILVA, Vagner Gonçalves da. Exu: o guardiáo da casa do futuro. Rio de Janeiro: Pallas, 2015.

STENGERS, Isabelle. Cosmopolitiques VII: pour en finir avec la tolérance. Paris: La Découverte, 1997.

Recebido em: 27/03/2020

Aprovado em: 25/06/2020 